\title{
IAMJ
}

INTERNATIONAL AYURVEDIC MEDICAL JOURNAL

\section{PHARMACEUTICO-ANALYTICAL STUDY AND QUALITY STANDARD DETECTION OF JATYADI GHRITA BY HPTLC METHOD}

\section{$\underline{\text { Priyanka Sharma }}^{1}, \underline{\text { K. Shankar Rao }}^{2}$}

${ }^{1}$ MD Ayu, Assist. Professor Dept. of RS \&BK, SSSB Ayurvedic College, Jaipur, Rajasthan, India ${ }^{2} \mathrm{PhD}$ Ayu, Professor \& HOD Rasa Shastra \& Bhaishajya Kalpana, NIA, Jaipur, Rajasthan, India

Corresponding Author: drshrampriyanka25@gmail.com

https://doi.org/10.46607/iamj02p4062020

(Published online: September 2020)

Open Access

(C) International Ayurvedic Medical Journal, India 2020

Article Received: 13/09/2020 - Peer Reviewed: 24/09/2020 - Accepted for Publication: 26/09/2020

Check for updates

\begin{abstract}
In the era of commercialization quality control and standardization of herbal formulation is essential in order to assess the quality of drugs for therapeutic value. Jatyadi Ghrita is a ghee based Ayurvedic formulation useful for treatment of all kind of wounds by external application found in classical texts of Ayurveda. In this study an attempt has been made to develop standard for Jatyadi Ghrita by HPTLC method. It was prepared by standard laboratory reference of Ayurvedic formulary of India in three batches in RS \& BK Laboratory NIA, Jaipur. The physicochemical tests performed on different samples of Jatyadi Ghrita such as acid value, saponification value, Total fatty matter, melting point, viscosity etc. Further standardization and comparative evaluation of laboratory sample and marketed sample done by instrument analysis performed on HPTLC finger printing profile. Data has been provided to demonstrate applicability of the methods to standardization of Jatyadi Ghrita.
\end{abstract}

Keywords: Jatyadi Ghrita, HPTLC Fingerprint Profile, Traditional medicine, Quality standard

\section{INTRODUCTION}

The traditional systems of medicine evolved over centuries had been responsible for safeguarding healthcare of the world until the advent of allopathic system of medicine. As the later system has used the knowledge of modern biology and chemistry, for both discovery and treatment. This system got fast acceptability among 
the users and now it occupies predominant space in the area of healthcare. In spite of this, the contribution of the traditional preparations, which are normally polyherbal, is increasing because of the general impression that these products are safe; while the single-molecule based modern drugs used in allopathic system can have severe adverse effects. ${ }^{1}$ Although Commercialization started disadvantages came forward peoples become doubtful regarding quality and genuinity of drugs what they had prescribed by the physician and what they are going to purchase, enquires scientific reasoning leads to introduction of quality control and standardization. The need of quality control for Ayurveda, Sidhha and Unani (ASU) drug is because the preparation of drug according to the ancient method has been reduced due to commercialization of Ayurvedic pharmacy during past era. $^{2}$

It should be renowned that herbal drug standardization is not new in Ayurveda. In the classics, it is point out in a codified manner i.e. Grahya Lakshana, Method of collection etc. for raw drug, Siddhi Lakshanas for final product and for medicament, Alpamatram, Mahavegam, Bahudoshaharam etc. properties are mentioned in Ayurvedic classics. Beside this, so many fundamental standards regarding drugs are available in our classics, which are primitive and limited to the time need of that stage. The concept of quality in those days was build up based on physical aspects of the plant materials such as identification, color, odor, size, age etc. Today there are addition to physical test and identification i.e. chemical composition. The Government of India has adopted the "Fingerprint" approach for botanicals because it supports the traditional concept and is easy to practice at different levels of sophistication. ${ }^{3}$

Jatyadi Ghrita is a ghee-based herbo-mineral formulation useful for wounds, painful ulcers, insect bite wounds, wounds caused by heat or fire and deep wounds by external application as per the classical texts of Ayurveda. ${ }^{4,5,6,7,8}$ As it is a popular classical formulation there is a need to standardize this formulation. Jatyadi ghrita marketed formulation J G M was chosen for analytical standardization and three Jatyadi Ghrita samples JGL1, JGL2, JGL3 were prepared in laboratory by same SOP for pharmaceutico-analytical standardization. The physicochemical tests performed on different samples of Jatyadi Ghrita such as specific gravity, acid value, saponification value, Total fatty matter, melting point, viscosity etc. to know their physico-chemical properties. Further standardization by instrument analysis performed on HPTLC for finger printing profile. Hence a comparative study of market sample and laboratory sample was done by sophisticated techniques such as HPTLC method to know the need for standardization of Ayurvedic formulations.

\section{Aim and Objectives -}

Preparation of Jatyadi Ghrita in three batches to standardization of pharmaceutical process. To evaluate physico-chemical parameters of the above samples. For further standardization Instrument analysis with HPTLC finger printing profile.

\section{Material \& Methods:}

One Jatyadi Ghrita formulation of Nagarjuna Ayurveda (batch no. PD8E) was purchased from local market of Chomu, Jaipur, Rajasthan and coded as JGM.

Pharmaceutical Study: All the raw materials were procured from the pharmacy and authenticated by Drug testing laboratory in Dept. Rasashastra and Bhaishajya Kalpana, National Institute of Ayurveda, Jaipur. Ingredients used in preparation of Jatyadi Ghrita are tabulated below.

Methods: Jatyadi Ghrita was prepared with proper method and standards as per the reference of $\mathrm{AFI}^{9}$ in 3 batches in the Dept. of Rasashastra and Bhaishajya kalpana laboratory, National institute of Ayurveda, Jaipur. Kalka was prepared by 2-12 drugs after cleaned that made into powder separately and pass through $250 \mu \mathrm{m}$ I.S. sieve then added water till the mixture become Kalka form. The quantity of fresh leaves was taken just double from other dry Kalka dravya's. ${ }^{10}$ Kalka Dravyas were transferred to the wet grinder and grind with sufficient quantity of water to prepare homogeneous blend. Ghrita Paka was done by Murchhita Goghrita, ${ }^{11}$ Kalka and Jala on mild heat \{between $50^{\circ}$ and $\left.90^{\circ}\right\}$ till Sneha Siddhi Lakshana appeared with intermittent stirring on $1^{\text {st }}$ and $2^{\text {nd }}$ day and continuous stirring on $3^{\text {rd }}$ day. It was filtered through muslin and Prakshepa Dravya were added to it. Shodhita Tuttha in 
$10 \mathrm{ml}$ water were mixed together and passed through muslin cloth. Bees wax was heated with some quantity of ghee on water bath at $100^{\circ} \mathrm{C}$. The copper sulphate solution was mixed it in melted condition with propeller mixer at 100 RPM for 15 min. and remaining Ghrita was added slowly with continuous stirring. Above same procedure was conducted in 3 samples of Jatyadi Ghrita.

\begin{tabular}{|c|c|c|c|c|}
\hline S. $\mathbf{N}$. & Name of the drugs & Part of use & Quantity & \\
\hline 1. & Murcchhita Goghruta & Cow's ghee & $768 \mathrm{~g}$ & 1 part- Sneha \\
\hline 2. & Jati Patra \{Jasminum grandiflorum\} & Fresh Leaf & $35 \mathrm{~g}$ & \multirow{11}{*}{$\begin{array}{l}1 / 4 \text { part } \\
\text { Kalka Dravya }\end{array}$} \\
\hline 3. & Nimba Patra $\{$ Azadirachta indica $\}$ & Fresh Leaf & $35 \mathrm{~g}$ & \\
\hline 4. & Patol Patra $\{$ Trichosanthes dioica\} & Dried Leaf & $17.45 \mathrm{~g}$ & \\
\hline 5. & Katuka \{Picrorhiza kurroa\} & Rhizome /Root & $17.45 \mathrm{~g}$ & \\
\hline 6. & Daruharidra $\{$ Berberis aristata $\}$ & Stem & $17.45 \mathrm{~g}$ & \\
\hline 7. & Haridra $\{$ Curcuma longa $\}$ & Rhizome & $17.45 \mathrm{~g}$ & \\
\hline 8. & Sariva Hemidesmus indicus $\}$ & Root & $17.45 \mathrm{~g}$ & \\
\hline 9. & Manjishtha $\{$ Rubia cordifolia $\}$ & Root & $17.45 \mathrm{~g}$ & \\
\hline 10. & Abhaya (Ushira) Vetiveria zizanioides & Root & $17.45 \mathrm{~g}$ & \\
\hline 11. & Madhuyashthi $\{$ Glycyrrhiza glabra\} & Root & $17.45 \mathrm{~g}$ & \\
\hline 12. & Karanja Beeja \{Pongamia pinnata\} & Seeds & $17.45 \mathrm{~g}$ & \\
\hline 13. & Jala & Potable water & $3.071 \mathrm{~kg}$ & 4 part-Drava \\
\hline 14. & Siktha & Bee's wax & $17.45 \mathrm{~g}$ & Prakshepa Dravya \\
\hline 15. & Tuttha $\{$ Copper sulphate\} & $\mathrm{CuSO}_{4}$ & $17.45 \mathrm{~g}$ & , \\
\hline
\end{tabular}

Analytical Study: The physicochemical analysis of Jatyadi Ghrita was conducted on the basis of parameters laid down by API at Ayushraj Enterprises Pvt. Ltd. Dehami Begas Road, Mansinghpura Jaipur and S.R. LABS Haldighati Marg, Pratap Nagar Jaipur. such as Organoleptic characters, Rancidity, Specific gravity, Refractive index, Viscosity, Iodine value, Acid value, Peroxide value, Saponification value etc. as per standard procedure of Ayurvedic Pharmacopoeia of India. ${ }^{12}$ HPTLC Fingerprint profile: HPTLC performed by TLC apparatus CAMAGE, Switzerland at Ayushraj Enterprises Pvt. Ltd. Dehami Begas Road, Mansinghpura Jaipur Instrument consists of Linomat 5 applicator, Scanner 4, photographic chamber and visualization chamber. The procedure was performed as per the reference of API. ${ }^{13}$

Conditions: Stationary phase: Pre-coated silica gel $60 \mathrm{~F}_{254}$ aluminum plates

Mobile phase: Toluene: Ethyl acetate: formic acid [6:3.5:0.5]

Chamber Saturation Time: 20 mins.
Test Solution: $2 \mathrm{~g}$ of every sample of JG were separately extracted by cold maceration in methanol and then filter the liquid extract and made the volume up to $50 \mathrm{ml}$ with methanol.

Derivatizing Reagent: Anisaldehyde Sulphuric acid Procedure: Previously dried TLC plate were taken and fix dimension at $\mathrm{X}$ position and mark from base with help of pencil at $10 \mathrm{~mm}$ and $90 \mathrm{~mm}$ and also left $20 \mathrm{~mm}$ from both sides of plate. The test sample solution was applied $6 \mu \mathrm{l}$ in the form of bands with the programming of Linomats applicator. Then solvent was allowed to be evaporated and place the plate in the saturated tank, possibly vertical and so that spots or bands are above the level of mobile phase. After closing the tank and allowed it to stand at room temperature until mobile phase ascended to the marked line. Remove the plate and dry and visualize as in UV light at $254 \mathrm{~nm}$. The photographs were taken of developed and derivatized TLC plate at $254 \mathrm{~nm}, 366 \mathrm{~nm} \&$ white light. Process was carried on derivatization of plate by dipping method in anisaldehyde reagent. Dried over $100^{\circ} \mathrm{C}$ for $15 \mathrm{~min}$ and visualize in day light. The scanning Programme for 
completely dried plate was prepared at different wavelength of $550 \mathrm{~nm}, 625 \mathrm{~nm}$ and $360 \mathrm{~nm}$. Comparative evaluation of the scanning parameter (Densitogram) is performed by final analysis report.

Observation \& Results: These are drawn in tables as below-

Table 1: Showing organoleptic characteristics of laboratory JG samples

\begin{tabular}{|l|l|l|l|l|}
\hline Sample & Color & Odor & Appearance & Clarity \\
\hline Murchita Ghrita & Yellowish green & Characteristic & Granular, oily & Opaque \\
\hline JGL1 & Greenish yellow & Characteristic & Granular, oily & Opaque \\
\hline JGL2 & Greenish yellow & Characteristic & Granular, oily & Opaque \\
\hline JGM & Greenish yellow & Characteristic & Granular, oily & Opaque \\
\hline
\end{tabular}

Table 2: Showing the weight loss of all samples of Jatyadi Ghrita in Sneha Paka Process.

\begin{tabular}{|l|l|l|l|l|l|}
\hline Name of the sample & $\begin{array}{l}\text { Initial weight of Mur- } \\
\text { cchhita Sneha }(\mathrm{g})\end{array}$ & $\begin{array}{l}\text { Weight of obtained } \\
\text { Jatyadi Ghrita }(\mathrm{g})\end{array}$ & $\begin{array}{l}\text { Loss of weight } \\
(\mathrm{g})\end{array}$ & $\begin{array}{l}\text { \% of loss } \\
\text { JGL-1 }\end{array}$ & $\begin{array}{l}\text { Mean of } \\
\text { loss }\end{array}$ \\
\hline JGL-2 & $768 \mathrm{~g} / 870 \mathrm{ml}$ & 695.5 & 72.5 & $9.4 \%$ & \\
\hline JGL-3 & $768 \mathrm{~g} / 870 \mathrm{ml}$ & 699 & 69 & $8.9 \%$ & $9.26 \%$ \\
\hline
\end{tabular}

Table 3: Comparative Physiochemical analysis of Jatyadi Ghrita (JG) samples

\begin{tabular}{|c|c|c|c|c|}
\hline \multirow[t]{2}{*}{ Physio-chemical Parameters } & \multicolumn{3}{|c|}{ Different Jatyadi Ghrita Laboratory Samples } & \multirow{2}{*}{$\begin{array}{l}\text { Jatyadi Ghrita Marketed sample } \\
\text { JGM }\end{array}$} \\
\hline & JGL1 & JGL2 & JGL3 & \\
\hline Acid Value & 2.98 & 2.28 & 1.91 & 2.99 \\
\hline Rancidity & Slightly rancid & Slightly rancid & Slightly rancid & Slightly Rancid \\
\hline Unsaponifiable Matter \% (w/w) & 0.97 & 0.88 & 1.02 & 0.89 \\
\hline Saponification value & 174.35 & 151.79 & 161.82 & 170.35 \\
\hline Total Fatty Matter $\%(w / w)$ & 88 & 81.3 & 84 & 82.3 \\
\hline Ester Value & 171.37 & 149.51 & 159.91 & 163.51 \\
\hline Refractive Index & 1.428 & 1.428 & 1.428 & 1.428 \\
\hline Specific Gravity & 0.925 & 0.930 & 0.916 & 0.929 \\
\hline Viscosity & $47 \mathrm{cp}\left(\right.$ At $\left.40^{\circ} \mathrm{C}\right)$ & - & - & $49 \mathrm{cp}\left(\mathrm{At} 40^{\circ} \mathrm{C}\right)$ \\
\hline Peroxide Value & 32.47 & 25.94 & 20.29 & 26.96 \\
\hline Iodine value & 5.08 & 7.48 & 4.75 & 7.52 \\
\hline Melting Point & $39^{0} \mathrm{C}$ & - & - & $40^{\circ} \mathrm{C}$ \\
\hline \multicolumn{5}{|l|}{ Heavy Metal Analysis } \\
\hline Lead & ND & - & - & - \\
\hline Cadmium & $0.038 \mathrm{ppm}$ & - & - & - \\
\hline Mercury & ND & - & - & - \\
\hline Arsenic & ND & - & - & - \\
\hline
\end{tabular}

Table 4: Showing Rf values obtained from HPTLC fingerprint profile of JG samples

\begin{tabular}{l|l|l|}
\hline $\begin{array}{l}\text { Scanning } \\
\text { Wavelengths }\end{array}$ & Rf Values of Major Spots & JGL1 \\
\cline { 2 - 3 } At $550 \mathrm{~nm}$ & $0.31,0.38,0.46,0.59,0.60,0.68,0.76,0.64$ & $0.13,0.19,0.32,0.39,0.47,0.53,0.59,0.64,0.68,0.78$ \\
\hline At $625 \mathrm{~nm}$ & $0.26,0.31,0.37,0.44,0.59,0.64,0.68,0.76$ & $0.13,0.19,0.27,0.32,0.38,0.47,0.53,0.59,0.64,0.68,0.77$ \\
\hline At $700 \mathrm{~nm}$ & $0.26,0.31,0.38,0.58,0.63,0.68,0.76$ & $0.13,0.19,0.27,0.32,0.36,0.38,0.45,0.59,0.64,0.69,0.79$ \\
\hline
\end{tabular}


Table 5: Showing the results of HPTLC of JG marketed \& laboratory samples

\begin{tabular}{|l|l|l|l|}
\hline Sample & $\mathbf{5 5 0} \mathbf{~ n m}$ wavelength & $\mathbf{6 2 5} \mathbf{~ n m}$ wavelength & $\mathbf{7 0 0}$ nm wavelength \\
\hline JGM & 8 spots visualize & 9 spots visualize & 9 spots visualize \\
\hline JGL1 & 11 spots visualize & 12 spots visualize & 12 spots visualize \\
\hline
\end{tabular}

The HPTLC Fingerprint profile of Jatyadi formulations are presented in figure 1-6

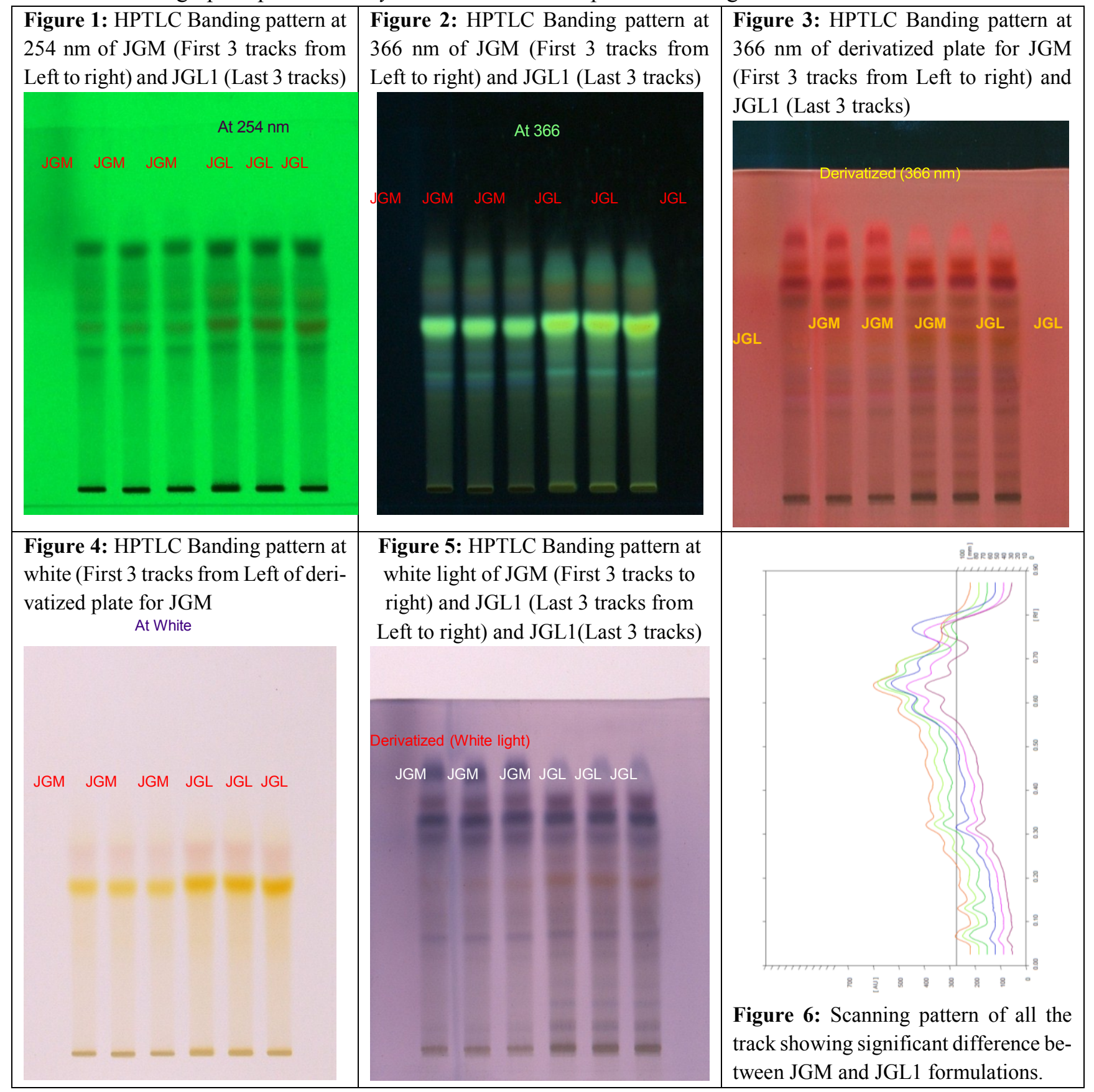

\section{DISCUSSION}

HPTLC study of methanolic extracts of the formulation
Jatyadi Ghrita's market sample and laboratory prepared samples were carried out. Inject the prepared and marketed sample solutions and qualitative analysis was 
carried out by comparison with respective peak areas. Samples were analyzed on different wavelengths $550 \mathrm{~nm}, 625 \mathrm{~nm}$ and $700 \mathrm{~nm}$. The scanning data shows different spots visualized get confirms the chemical nature and distribution pattern in specified mobile phase. The HPTLC fingerprint profiles of the formulations are presented in Figure 1-5. It confirms 8-9 distinct spots of marketed Jatyadi Ghrita sample and 11-12 distinct spots of laboratory prepared Jatyadi Ghrita sample. Figure 6 shows JGM have 8-9 peaks areas and JGL have 11-13 peak areas. HPTLC fingerprint comparison of JGM and JGL was clearly designated the more spots in JGL at lower Rf values which confirm extraction and stability of more secondary metabolites instead of JGM formulation. The Rf values of spots differentiate the samples chemical composition and formulation. Also, the visible pattern and colors of spots at $550 \mathrm{~nm}$ confirms the samples standardization in visible spectrum. Results of Physico-chemical parameters follows the range of standards laid down by Ayurvedic Pharmacopeia of India for Jatyadi Ghrita formulation and heavy metals are also in permissible limits that shows safety and quality of the formulation.

\section{CONCLUSION}

Hence, we can conclude HPTLC Fingerprint profiles confirm standard scanning of samples to generate the standardization parameter for quality control purpose. Comparative evaluation of physico-chemical parameters confirmed that Jatyadi Laboratory samples and marketed samples are not very much differ in their characterization. Related physico-chemical tests and HPTLC profile clearly shows the more stability of formulation and increased number of secondary metabolite extraction in laboratory sample than marketed sample of Jatyadi Ghrita. Possibly the above results denote standardization by sophisticated techniques is need of today.

\section{REFERENCES}

1. Deshpande S, Deshpande A, Tupkari S \& Agnihotri A, Shata - Dhauta-Ghrita-A case study. Indian Journal of Traditional Knowledge.2009 July vol-8(3) pg.no.387.

2. Anonymous, The Ayurvedic formulary of India. (Ministry of health and family welfare, Dept. of Indian systems of medicine and homeopathy). New Delhi; $2^{\text {nd }} e d$. 2003. Part-I, Introduction, pg no.17-18.

3. Vite Manisha H., Nangude S, Chugh N., Standardization of Jatyadi ghrita by HPTLC method. International journal of Research in Ayurveda \& Pharmacy.2013; Vol.4 (3) pg. no.367.

4. Pt. Ambika Dutt Shastri, Kaviraj Govind das Sen's Bhaishjya Ratnavalli, Chaukhamba Prakashan, Reprint edition 2014, Vranashotha chikitsa adhyaya verse-53, Page No.849.

5. Dr. Brahmananada Tripathi, Shargandhar Samhita of Shargandharacharya with Deepika Hindi commentary, published by Chaukhambha Surabharati Prakashana Varanasi, Reprint edition, 2011, Madhyama Khanda, navamodhyaya verse-58-51, pg.no-226.

6. Kaviraja Atrideva Gupta, Ashtangaahridayam of Vagbhata Vidyotini Hindi Commentary, Reprint edition Yadunandana Upadhyaya Editor, Varanasi: Chaukhambha Prakashana, 2011, Uttarasthan Vranavigyanapratishedadhyaya verse-67, pg no-741.

7. Dr. Indradeva Tripathi, Chakratadatta of Shri Chakrapanidatta Vaidhyaprabha Hindi Commentary, Reprint edition Ramanath Dwivedi Editor,Varanasi ;Chaukhambha Sanskrita Bhawan,2014,Vranashotha chikitsa verse-74, pg.no.-264.

8. Dr. Indradev Tripathi, Daya Shankar Tripathi, Yogaratnakar Vaidhyaprabha Hindi Commentary, Edition fourth, 2013, Varanasi; Chaukhambha Krishnadas Academy, Vranashotha Chikitsa Shodhan Ropana vidhi verse-84, pg. no.-613.

9. Anonymous, Electronic version of The Ayurvedic Formulary of India, Version-1.0, 2003, Published by The controller of publications, Civil lines, Delhi-170054. Page No 246-247.

10. Dr. Brahmananada Tripathi, Shargandhar Samhita of Sharnagadharacharya with Deepika hindi commentary, published by Chaukhambha Surabharati Prakashana Varanasi, Edition Reprint, 2011, Purva Khanda,1/48, pg.no-16.

11. Pt. Ambika Dutt Shastri, Kaviraj Govind das Sen's Bhaishjya Ratnavalli, Chaukhamba Prakashan, Reprint 
2014, Jawarachikitsaprakaranam, Verse-1284, Page No.185.

12. Anonymous, Ayurvedic pharmacopeia of India, Part-I, e-Book, Volumes-IV, 2004, Appendices 2.3.3 and 3.1.3., pg. no.-158-163

13. Anonymous, Ayurvedic pharmacopoeia of India, Govt. of India, New Delhi, Published in 2011, Part1, Vol.VIII, Appendices 3.5, Pg. no.-220.

\section{Source of Support: Nil \\ Conflict of Interest: None Declared}

How to cite this URL: Priyanka Sharma \& K. Shankar Rao: Pharmaceutico-Analytical Study and Quality Standard Detection of Jatyadi Ghrita By HPTLC Method. International Ayurvedic Medical Journal \{online\} 2020 \{cited September, 2020\} Available from: http://www.iamj.in/posts/images/upload/2462_2468.pdf 